\title{
Chemical Reactivity of Isoproturon, Diuron, Linuron, and Chlorotoluron Herbicides in Aqueous Phase: A Theoretical Quantum Study Employing Global and Local Reactivity Descriptors
}

\author{
Luis Humberto Mendoza-Huizar \\ Centro de Investigaciones Químicas, Universidad Autónoma del Estado de Hidalgo, Carretera Pachuca-Tulancingo Km 4.5, \\ 42186 Mineral de la Reforma, HGO, Mexico
}

Correspondence should be addressed to Luis Humberto Mendoza-Huizar; hhuizar@uaeh.edu.mx

Received 10 March 2015; Accepted 25 April 2015

Academic Editor: Yuan-Pern Lee

Copyright (C) 2015 Luis Humberto Mendoza-Huizar. This is an open access article distributed under the Creative Commons Attribution License, which permits unrestricted use, distribution, and reproduction in any medium, provided the original work is properly cited.

We have calculated global and local DFT reactivity descriptors for isoproturon, diuron, linuron, and chlorotoluron herbicides at the MP2/6-311++G(2d,2p) level of theory. The results suggest that, in aqueous conditions, chlorotoluron, linuron, and diuron herbicides may be degraded by elimination of urea moiety through electrophilic attacks. On the other hand, electrophilic, nucleophilic, and free radical attacks on isoproturon may cause the elimination of isopropyl fragment.

\section{Introduction}

Phenylurea herbicides (PUHs) are an important group of pesticides which have been broadly used in agriculture. These herbicides have been used for selective pre- and postemergence weed control on crops such as asparagus, beans, cotton, maize, fruit, and wheat [1-3]. Recently, PUHs have received particular attention because of their high biotoxicity and possible carcinogenic properties [4]. Also, it is important to mention that because of their low volatility, slow biodegradation, and low sorption in soils, PHUs have been frequently detected in surface, ground, and even drinking water [5], by which they have the potential to impact ground water quality [6]. Moreover, this kind of compounds requires several weeks to months for their removal from the environment [7], and they have been considered as priority hazardous substances [8].

Specifically, the PUHs 3-(4-isopropylphenyl)-1,1-dimethyl urea (isoproturon), 3-(3,4-dichlorophenyl)-1,1-dimethylurea (diuron), 3-(3,4-diclorofenil)-1-metoxi-1-metilurea (linuron), and 3-(3-chloro-p-tolyl)-1,1-dimethylurea (chlorotoluron) are slowly degraded in water and are quite persistent $[8,9]$, and it is increasingly common to find their parent compounds and metabolites in groundwater in concentrations exceeding the drinking water threshold limit of $0.1 \mu \mathrm{g} \mathrm{L}^{-1}[10,11]$. In animals, a long term exposure to large amounts of these PHUs has shown to cause tumors in kidneys, decreased red blood cells, liver enlargement, growth retardation, increased mortality, enlarged spleens, splenic hemosiderosis, and chronic methemoglobinemia, among others [12]. Although, there are so far no reported incidences of human poisoning, based on effects seen in animals, acute exposure to PHUs would be expected to cause mild skin irritation and headaches, drowsiness, and lack of coordination [13]. Thus, the efforts of many researchers have been focused on developing new and efficient remediation treatments to clean these phenylurea herbicides from the environment. Probably, Advanced Oxidation Processes (AOPs) [11, 14-22] and microbial [23-26] degradation methods are the preferred techniques to degrade this group of herbicides along with fungal degradation techniques [10, 27-29]. However, it has been reported that AOPs may produce harmful intermediates [30-32], while microbial and fungal degradation methods are 
unable to degrade completely these PHUs $[29,33]$. In soils, it has been observed that these herbicides may be degraded through demethylation at the urea nitrogen by mean enzymatic and microbial activity [34]. However, in aqueous conditions, the molecular basis for the initial degradation of these phenylurea herbicides remains unknown $[35,36]$.

Therefore, there is great interest in understanding the initial degradation pathways of this set of herbicides in order to develop new methods for degrading phenylurea herbicides in water. In this sense a detailed knowledge of the reactivity exhibited by isoproturon, diuron, linuron, and chlorotoluron at the molecular level may become fundamental to recognize their degradation mechanism in aqueous conditions. However, a study of the pinpoint distribution of the reactivity of these PHUs requires making precise measurements at the molecular level which may become experimentally complicated. In this sense, an advantage of the theoretical quantum methods resides in the fact that the electronic properties of the molecules may be calculated with enough accuracy, at the molecular level, to explain adequately the experimental behavior. Nevertheless, only few theoretical studies have analyzed the electronic properties of isoproturon, diuron, linuron, and chlorotoluron. Worrall and Thomsen calculated quantum and topological descriptors for linuron and diuron which were related to their biological activity [37]. In other study, the fragmentation pathways of the anionic forms of diuron were investigated employing the Density Functional Theory (DFT) [38] while the structure and vibrational spectrum of chlorotoluron and isoproturon were analyzed by Q. Wang and H. L. Wang [39] and Vrielynck et al. [40], respectively. However, to the best of our knowledge, isoproturon, diuron, linuron, and chlorotoluron reactivity, at the molecular level, has not been analyzed yet. Therefore, in this work we have analyzed the molecular reactivity of isoproturon, diuron, linuron, and chlorotoluron employing the global and local reactivity descriptors derived from DFT. We consider that this kind of study will contribute to get a better understanding of the chemical behavior in aqueous media of these PHUs herbicides.

\section{Theory}

The general behavior of a molecular system may be analyzed employing the global reactivity parameters derived from the Density Functional Theory. The typical parameters employed are the electronic chemical potential $(\mu)$, the electronegativity $(\chi)$, and hardness $(\eta)$, which are defined through the following equations [41-47]:

$$
\begin{aligned}
& \mu=\left(\frac{\partial E}{\partial N}\right)_{\nu(r)}=-\frac{1}{2}(I-A), \\
& \chi=-\mu, \\
& \eta=\left(\frac{\partial \mu}{\partial N}\right)_{\nu(r)}=\left(\frac{\partial^{2} E}{\partial N^{2}}\right)_{\nu(r)}=(I-A) .
\end{aligned}
$$

In these equations, $E, N$, and $\nu(r)$ are the energy, number of electrons, and the external potential of the system, respectively. The energy value of the vertical electronic affinity $(A)$ can be calculated as $A=E(N)-E(N+1)$, where $E(N)$ and $E(N+1)$ are the total ground-state energies in the neutral $N$ and singly charged $(N+1)$ configurations. On the other hand, the ionization potential $(I)$ can be calculated as $I=$ $E(N-1)-E(N)$. The chemical potential can be related to the escaping tendency of an electron and is characteristic of the molecular electronegativity [48], while $\eta$ has been related to the polarizability of the molecular system $[49,50]$. Additional to $\mu, \chi$, and $\eta$, the global electrophilicity index $\omega$ can be written as [51]

$$
\omega=\frac{\mu^{2}}{2 \eta} .
$$

This index measures the susceptibility of chemical species to accept electrons, by which, low values of $\omega$ indicate the presence of good nucleophiles, while good electrophiles are characterized by higher values of $\omega$ [51].

Additional to the global reactivity parameters, it has been possible to define local reactivity parameters $[52,53]$, such as the Fukui Function $(f(\vec{r}))[54,55]$. The Fukui function can be written as [56]

$$
f(\vec{r})=\left(\frac{\partial \rho(\vec{r})}{\partial N}\right)_{\nu(r)}=\left(\frac{\partial \mu(\vec{r})}{\partial \nu(r)}\right),
$$

where $\rho(\vec{r})$ is the electronic density. The Fukui function, equation (5), can be evaluated by using a finite difference approximation. However, due to the discontinuity of the electron density with respect to the number of electrons $(N)$, this approximation leads to three types of Fukui Function for a system, namely, $f^{+}(\vec{r}), f^{-}(\vec{r})$, and $f^{0}(\vec{r})$ for nucleophilic, electrophilic, and free radical attacks, respectively [52]. These condensed functions can be written as [52]

$$
\begin{aligned}
& f^{+}(\vec{r})=\rho_{N+1}(\vec{r})-\rho_{N}(\vec{r}), \\
& f^{-}(\vec{r})=\rho_{N}(\vec{r})-\rho_{N-1}(\vec{r}), \\
& f^{0}(\vec{r})=\frac{1}{2}\left[\rho_{N+1}(\vec{r})-\rho_{N-1}(\vec{r})\right] .
\end{aligned}
$$

However, for studying the reactivity at the atomic level, a more convenient way of calculating the Fukui function is through the condensed forms of Fukui functions for an atom $j$ in a molecule which are expressed as [52]

$$
\begin{aligned}
& f_{j}^{+}(\vec{r})=q_{j(N)}-q_{j(N+1)}, \\
& f_{j}^{-}(\vec{r})=q_{j(N-1)}-q_{j(N)}, \\
& f_{j}^{0}(\vec{r})=\frac{1}{2}\left\{q_{j(N-1)}-q_{j(N+1)}\right\} .
\end{aligned}
$$

In these equations, $q_{j}$ is the atomic charge (evaluated from Mulliken population, electrostatic derived charge, etc.) at the $j$ th atomic site in the neutral $(N)$, anionic $(N+1)$, or cationic $(N-1)$ chemical species. 


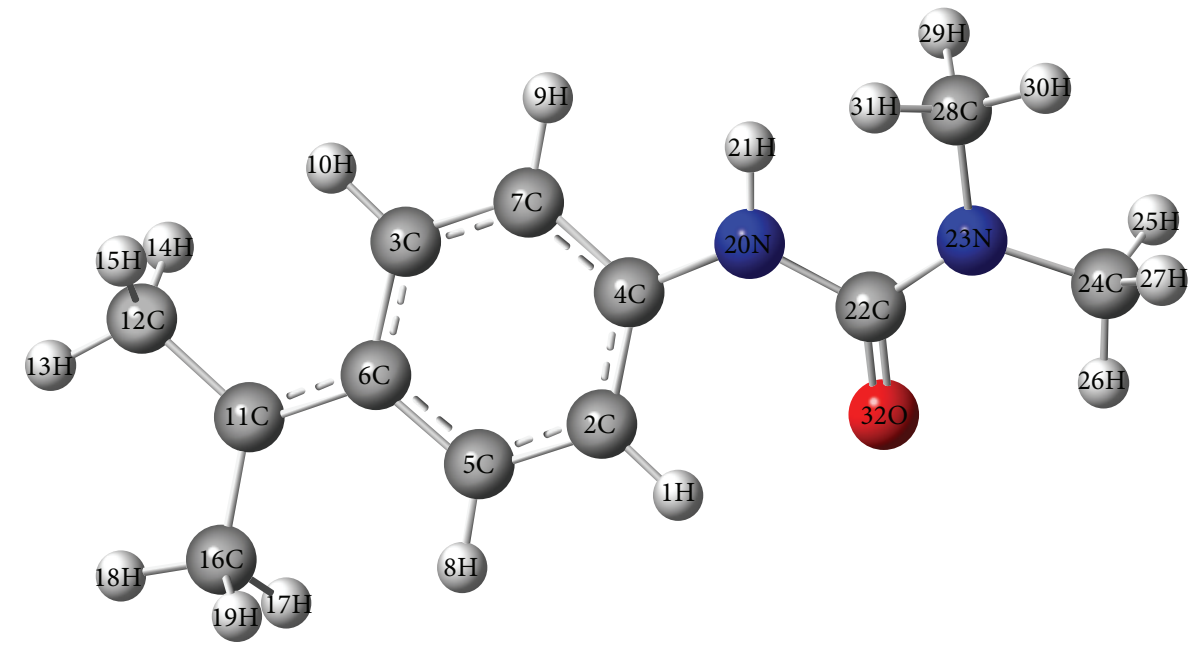

Figure 1: Optimized structure of isoproturon at the MP2/6-311++G(2d,2p) level of theory. Bond distances: $2 \mathrm{C}-4 \mathrm{C}=1.39,2 \mathrm{C}-5 \mathrm{C}=1.37,3 \mathrm{C}-$ $6 \mathrm{C}=1.40,3 \mathrm{C}-7 \mathrm{C}=1.36,4 \mathrm{C}-7 \mathrm{C}=1.39,5 \mathrm{C}-6 \mathrm{C}=1.40,6 \mathrm{C}-11 \mathrm{C}=1.43,11 \mathrm{C}-12 \mathrm{C}=1.50,11 \mathrm{C}-16 \mathrm{C}=1.50,4 \mathrm{C}-20 \mathrm{~N}=1.40,20 \mathrm{~N}-22 \mathrm{C}=1.39,22 \mathrm{C}-23 \mathrm{~N}=$ $1.37,22 \mathrm{C}-32 \mathrm{O}=1.24,23 \mathrm{~N}-28 \mathrm{C}=1.46,23 \mathrm{~N}-24 \mathrm{C}=1.46, \mathrm{~N}-\mathrm{H}=1.00, \mathrm{C}-\mathrm{H}=1.09$ in methyl groups, and $\mathrm{C}-\mathrm{H}=1.08$ in the ring. Dihedral angle $12 \mathrm{C}-11 \mathrm{C}-6 \mathrm{C}-3 \mathrm{C}=-0.2,2 \mathrm{C}-4 \mathrm{C}-20 \mathrm{~N}-22 \mathrm{C}=22.03$.

\section{Methodology}

The optimal conformations of isoproturon, chlorotoluron, diuron, and linuron were subjected to full geometry optimization in the gas phase employing the hybrid functional B3LYP [57-59] and the basis set 6-311++G(2d,2p) [60,61]. The optimized molecules in the gas phase were further reoptimized at the B3LYP/6-311++G(2d,2p) level employing the PCM solvation model $[62,63]$, with the dielectric constant 78.5 for water at $25^{\circ} \mathrm{C}$. The vibrational frequencies were computed to make sure that the stationary points were minima in the potential energy surface. Finally, the optimized B3LYP/6$311++\mathrm{G}(2 \mathrm{~d}, 2 \mathrm{p})$ geometries were reoptimized employing the second order Møller Plesset theory (MP2) [64] with the basis set $6-311++G(2 d, 2 p)$ in the aqueous phase. The final atomic charges for isoproturon, chlorotoluron, diuron, and linuron were obtained in the framework of MP2 theory; in all calculations of these atomic charges, the option DENSITY = MP2 was used. All the calculations here reported were performed with the package Gaussian 09 [65] and visualized with GaussView V. 2.08 [66].

\section{Results and Discussion}

The isoproturon, diuron, linuron, and chlorotoluron structures were optimized at the B3LYP/6-311++G (2d,2p) level in the gas phase. In order to take into account the effect of solvation on the electronic properties of isoproturon, diuron, linuron, and chlorotoluron, the optimized structures in the gas phase were used as starting point to reoptimize them at the B3LYP/6-311++G(2d,2p) level without any symmetry constraints employing the PCM solvation model. In all cases a frequency analysis was applied to the optimized geometries to verify the stability criterion and in all cases the frequency values were positive. Thus, it could be identified stretching $\mathrm{N}-\mathrm{H}$ vibrations at $3639,3644,3593$, and $3645 \mathrm{~cm}^{-1}$, strong
TABLE 1: Electronic energies calculated at the MP2/6-311++G(2d,2p) level of theory.

\begin{tabular}{lccc}
\hline & Cation $/ E_{h}$ & Neutral $/ E_{h}$ & Anion $/ E_{h}$ \\
\hline Isoproturon & -650.482060 & -650.608629 & -650.728242 \\
Chlorotoluron & -1031.69563 & -1031.95653 & -1031.97778 \\
Diuron & -1451.54737 & -1451.81897 & -1451.84796 \\
Linuron & -1526.57888 & -1526.85348 & -1526.88449 \\
\hline
\end{tabular}

stretching vibrations of the carbonyl bond at 1663, 1675, 1688, and $1670 \mathrm{~cm}^{-1}$, while N-C-N symmetric stretching vibrations were observed at $1032,1043,1039$, and $1039 \mathrm{~cm}^{-1}$, for isoproturon, diuron, linuron, and chlorotoluron, respectively. These values compare favorably with those values reported in the literature for phenylurea compounds $[67,68]$. Also, the structures optimized at the B3LYP/6-311++G(2d,2p) level were further reoptimized at the MP2/6-311++G(2d,2p) level in the aqueous phase; see Figures 1, 2, 3, and 4. The bond distances and angles obtained at the MP2/6-311++G(2d,2p) levels are comparable with those reported in the literature $[68,69]$.

\section{Global Reactivity Descriptors}

The global reactivity descriptors in the aqueous phase for isoproturon, chlorotoluron, diuron, and linuron were obtained at the MP2/6-311++G(2d,2p) level of theory. In Table 1, the values of the electronic energies calculated for these herbicides with the charges $+1,0$, and -1 are reported, which correspond to the cationic, neutral, and anionic species, respectively. The values reported in Table 1 were used to calculate the global reactivity descriptors $(\mu$, $\eta$, and $\omega$ ) through (1), (3), and (4); see Table 2. Note that the values of hardness and chemical potential are following 


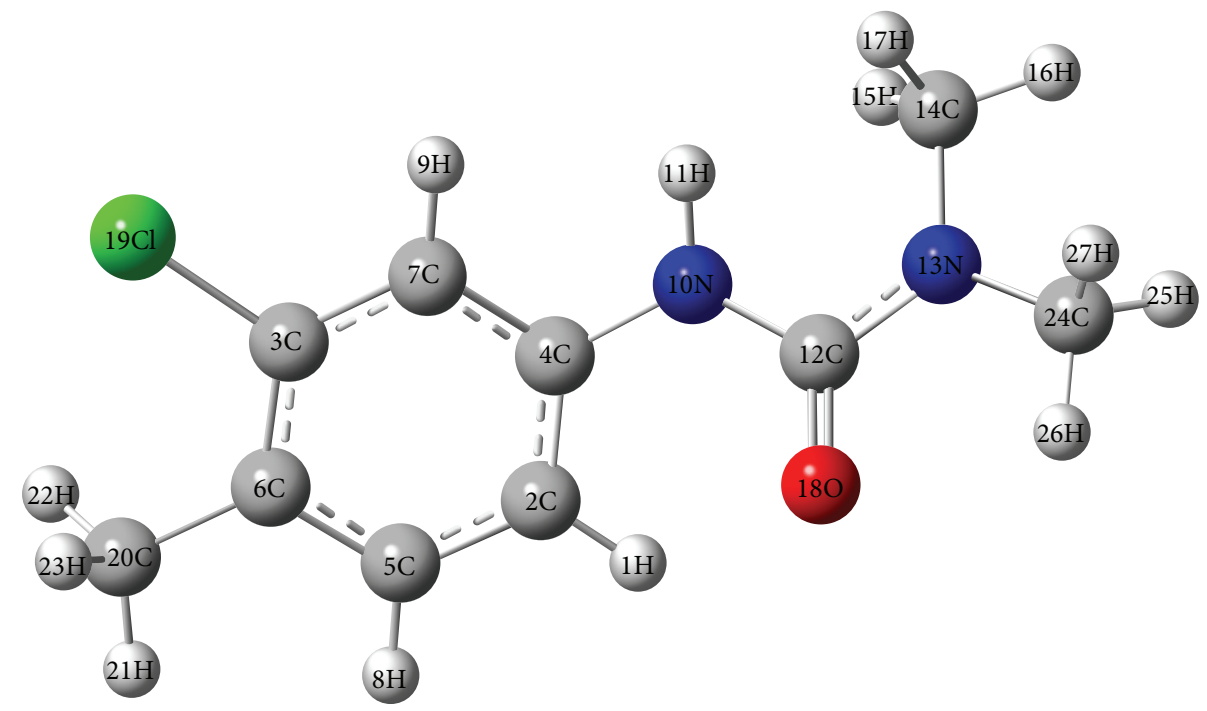

Figure 2: Optimized structure of chlorotoluron at the MP2/6-311++G(2d,2p) level of theory. Bond distances: $2 \mathrm{C}-4 \mathrm{C}=1.40,2 \mathrm{C}-5 \mathrm{C}=1.39,3 \mathrm{C}-$ $6 \mathrm{C}=1.40,3 \mathrm{C}-7 \mathrm{C}=1.39,4 \mathrm{C}-7 \mathrm{C}=1.40,5 \mathrm{C}-6 \mathrm{C}=1.40,6 \mathrm{C}-20 \mathrm{C}=1.50,3 \mathrm{C}-19 \mathrm{Cl}=1.76,4 \mathrm{C}-10 \mathrm{~N}=1.41,10 \mathrm{~N}-12 \mathrm{C}=1.39,12 \mathrm{C}-18 \mathrm{O}=1.24,12 \mathrm{C}-13 \mathrm{~N}=$ $1.36,13 \mathrm{~N}-24 \mathrm{C}=1.45,13 \mathrm{~N}-14 \mathrm{C}=1.46, \mathrm{~N}-\mathrm{H}=1.00, \mathrm{C}-\mathrm{H}=1.09$ in methyl groups, and $\mathrm{C}-\mathrm{H}=1.08$ in the ring. Dihedral angle $2 \mathrm{C}-4 \mathrm{C}-10 \mathrm{~N}-12 \mathrm{C}=$ $-17.53,10 \mathrm{~N}-12 \mathrm{C}-13 \mathrm{~N}-21 \mathrm{O}=18.34$.

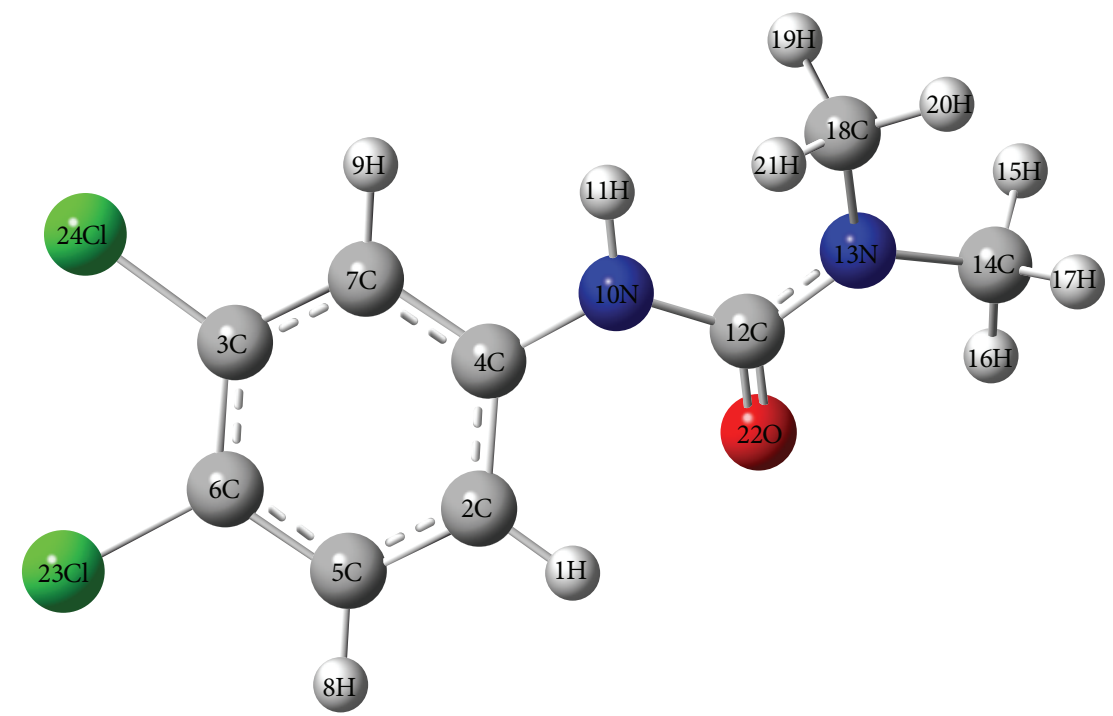

Figure 3: Optimized structure of diuron at the MP2/6-311++G(2d,2p) level of theory. Bond distances: $2 \mathrm{C}-4 \mathrm{C}=1.40,2 \mathrm{C}-5 \mathrm{C}=1.39,3 \mathrm{C}-6 \mathrm{C}=$ $1.40,3 \mathrm{C}-7 \mathrm{C}=1.39,4 \mathrm{C}-7 \mathrm{C}=1.40,5 \mathrm{C}-6 \mathrm{C}=1.39,6 \mathrm{C}-23 \mathrm{Cl}=1.74,3 \mathrm{C}-24 \mathrm{Cl}=1.74,4 \mathrm{C}-10 \mathrm{~N}=1.40,10 \mathrm{~N}-12 \mathrm{C}=1.40,12 \mathrm{C}-22 \mathrm{O}=1.24,12 \mathrm{C}-13 \mathrm{~N}=$ $1.36,13 \mathrm{~N}-18 \mathrm{C}=1.46,13 \mathrm{~N}-14 \mathrm{C}=1.46, \mathrm{~N}-\mathrm{H}=1.00, \mathrm{C}-\mathrm{H}=1.09$ in methyl groups, and $\mathrm{C}-\mathrm{H}=1.08$ in the ring. Dihedral angle $2 \mathrm{C}-4 \mathrm{C}-10 \mathrm{~N}-12 \mathrm{C}=$ 40.3 .

the order: linuron $>$ diuron $>$ chlorotoluron $>$ isoproturon. Last result suggests that linuron is the most stable specie of this set of herbicides, while isoproturon result to be the most reactive. Also, note that chlorotoluron exhibits the lower value of $\omega$ which indicates that it is better nucleophile in comparison to isoproturon, diuron, and linuron. Note that $\mu$, $\eta$, and $\omega$ are global type response functions that characterize the molecule as a whole which allow us to characterize global reactivity trends [41]. However, it is important to evaluate local reactivity descriptors as the condensed Fukui function to analyze the pinpoint distribution of the reactivity in the molecule in order to propose specific degradation mechanisms.

\section{Local Reactivity Descriptors for Neutral CPAs}

For the PHUs analyzed in the present work, the values of the condensed Fukui function for electrophilic, nucleophilic, and free radical attacks were evaluated through (7). It is important to mention that the values of the Fukui function are dependent on the scheme of charges used. Thus, it is 


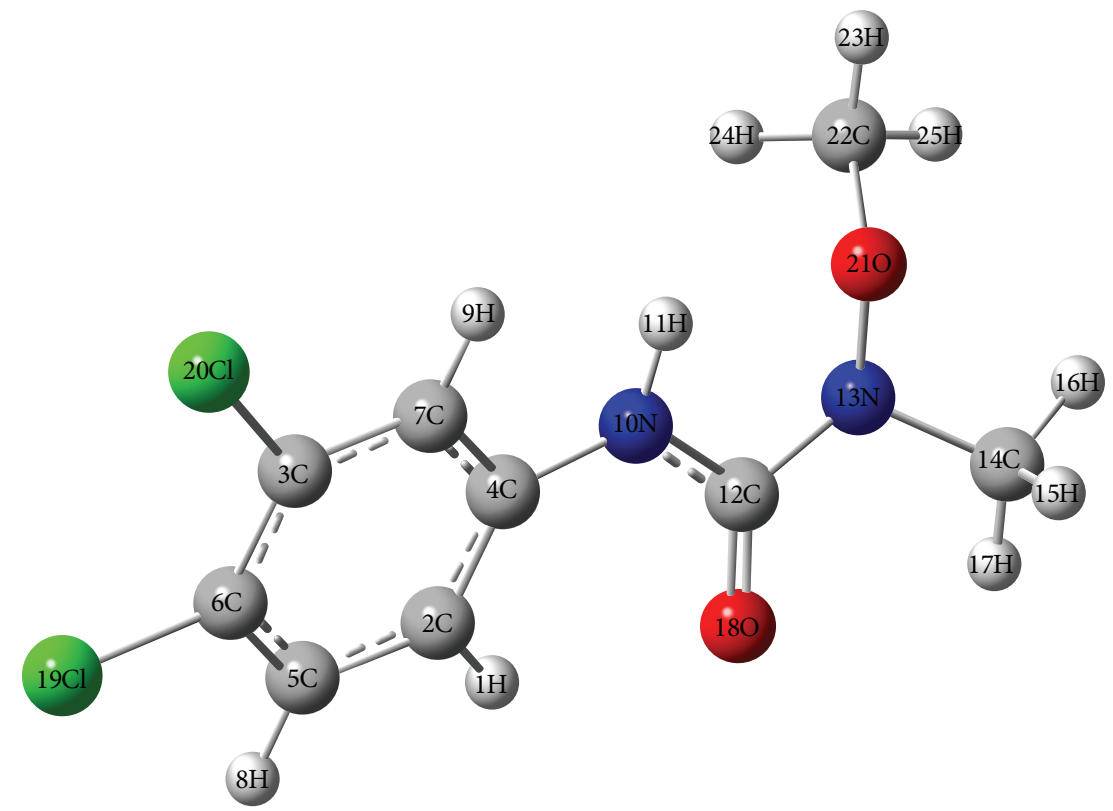

Figure 4: Optimized structure of linuron at the MP2/6-311++G(2d,2p) level of theory. Bond distances: $2 \mathrm{C}-4 \mathrm{C}=1.40,2 \mathrm{C}-5 \mathrm{C}=1.39,3 \mathrm{C}-6 \mathrm{C}=$ $1.40,3 \mathrm{C}-7 \mathrm{C}=1.39,4 \mathrm{C}-7 \mathrm{C}=1.40,5 \mathrm{C}-6 \mathrm{C}=1.39,6 \mathrm{C}-19 \mathrm{Cl}=1.74,3 \mathrm{C}-20 \mathrm{Cl}=1.74,4 \mathrm{C}-10 \mathrm{~N}=1.40,10 \mathrm{~N}-12 \mathrm{C}=1.37,12 \mathrm{C}-18 \mathrm{O}=1.23,12 \mathrm{C}-13 \mathrm{~N}=$ $1.40,13 \mathrm{~N}-21 \mathrm{O}=1.42,13 \mathrm{~N}-14 \mathrm{C}=1.46,21 \mathrm{O}-22 \mathrm{C}=1.44, \mathrm{~N}-\mathrm{H}=1.00, \mathrm{C}-\mathrm{H}=1.09$ in methyl groups, and $\mathrm{C}-\mathrm{H}=1.08$ in the ring. Dihedral angle $2 \mathrm{C}-4 \mathrm{C}-10 \mathrm{~N}-12 \mathrm{C}=-17.53,10 \mathrm{~N}-12 \mathrm{C}-13 \mathrm{~N}-21 \mathrm{O}=18.34$.

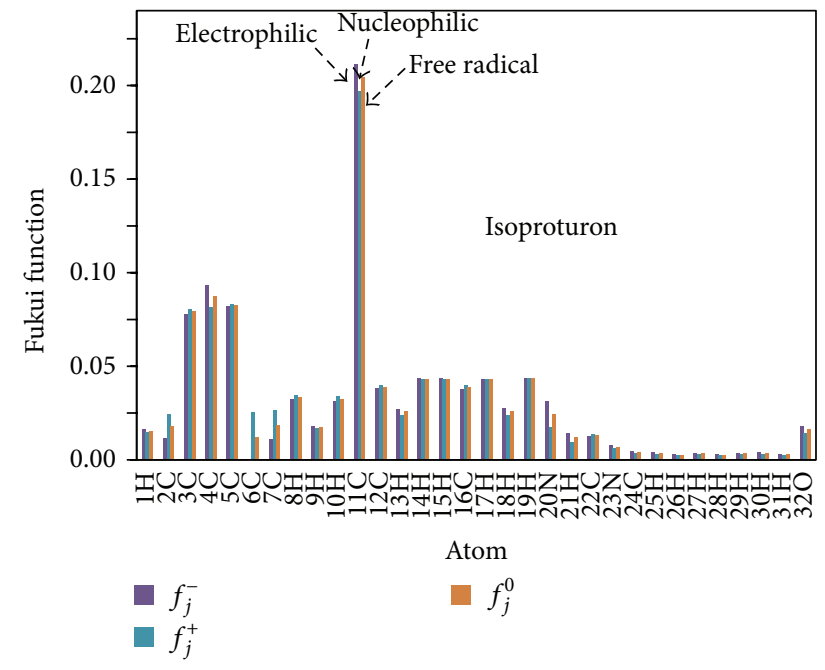

Figure 5: Values of the Fukui function for isoproturon considering Hirshfeld charges according to (7).

well known that the Fukui function values obtained from various population schemes may provide negative values; however, the Hirshfeld Stockholder population scheme [70] yields positive values [71]. Therefore, Hirshfeld partitioning scheme was used to derive the atomic charges at the MP2/6$311++\mathrm{G}(2 \mathrm{~d}, 2 \mathrm{p})$ level. In Figures 5, 6, 7, and 8 the values of the condensed Fukui function for isoproturon, chlorotoluron, diuron, and linuron are reported, respectively. From Figure 5, observe that for isoproturon the more reactive sites to electrophilic, nucleophilic, or free radical attacks are located

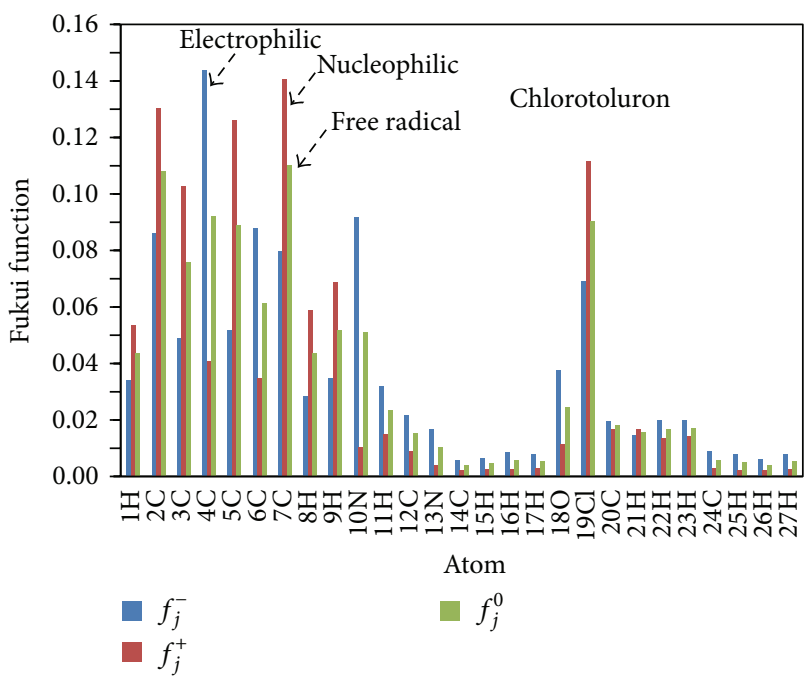

FIgURE 6: Values of the Fukui function for chlorotoluron considering Hirshfeld charges according to (7).

interchangeably on 11C. Last result suggests that chemical attacks on $11 \mathrm{C}$ would cause the elimination of the isopropyl moiety. The Fukui function values for chlorotoluron are reported in Figure 6; note that the distribution of the more reactive sites for this herbicide are located on $4 \mathrm{C}, 7 \mathrm{C}$, and $7 \mathrm{C}$ atoms for electrophilic, nucleophilic, and free radical attacks, respectively. Also, it is possible to deduce that electrophilic attacks on $4 \mathrm{C}$ would cause the elimination of the metoxi1-metilurea moiety. On the other hand, the atom $7 \mathrm{C}$ is susceptible to either nucleophilic or free radical substitutions. 


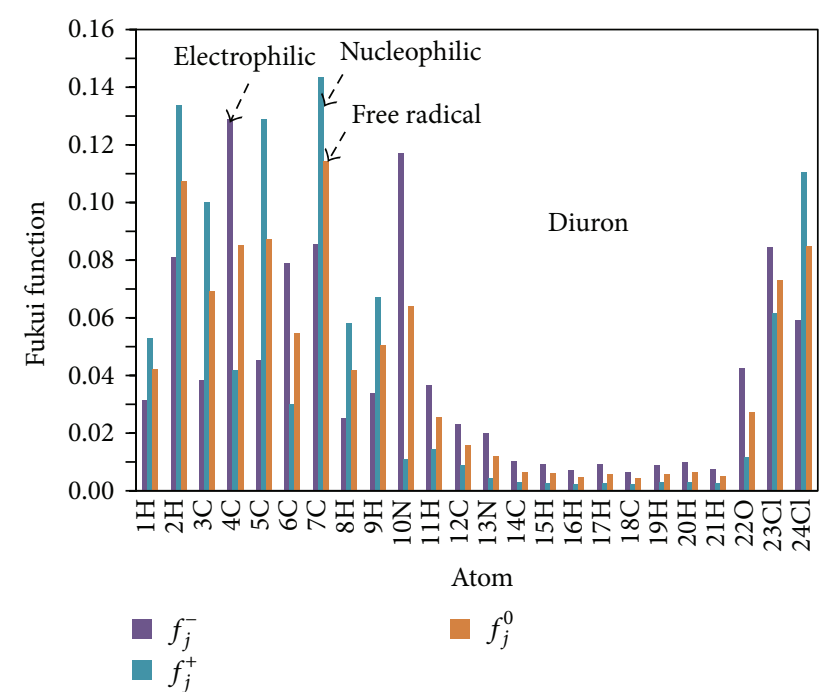

FIGURE 7: Values of the Fukui function for diuron considering Hirshfeld charges according to (7).

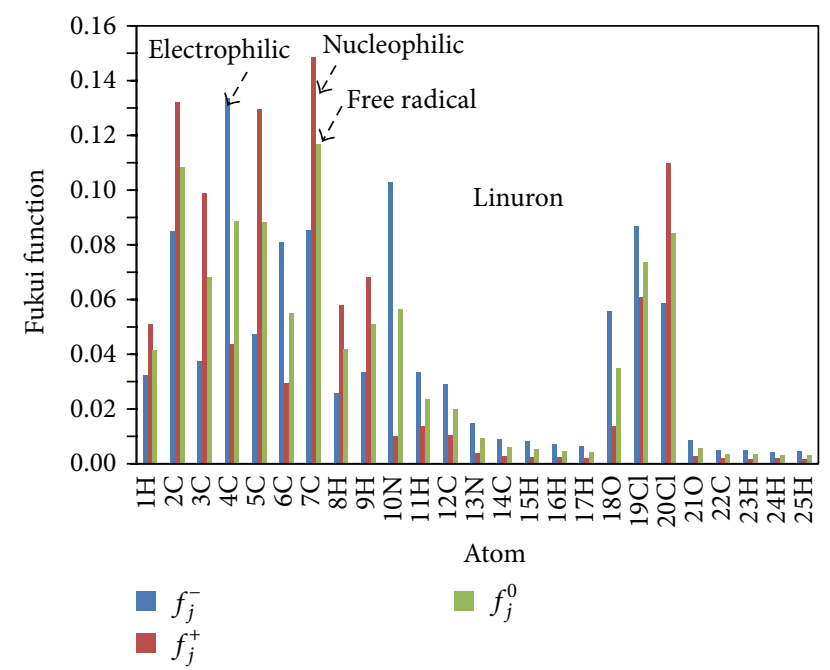

FIgURE 8: Values of the Fukui function for linuron considering Hirshfeld charges according to (7).

Here, it is interesting to highlight that the values of the Fukui Function found for diuron (see Figure 7) and linuron (see Figure 8) indicate that the more reactive sites are located on 4C, 7C, and 7C. Thus, nucleophilic and free radical attacks on diuron and linuron would cause a substitution of the hydrogen atom on $7 \mathrm{C}$, while electrophilic attacks on diuron and chlorotoluron would cause the elimination of the dimethylurea fragment.

\section{Conclusions}

In the present work, we have analyzed the chemical reactivity of isoproturon, chlorotoluron, diuron, and linuron herbicides in the aqueous phase employing global and local reactivity
TABLE 2: Global reactivity descriptors for isoproturon, chlorotoluron, diuron, and linuron at the MP2/6-311++G(2d,2p) level of theory, in the aqueous phase.

\begin{tabular}{lccccc}
\hline & $I / \mathrm{eV}$ & $\mathrm{A} / \mathrm{eV}$ & $\eta / \mathrm{eV}$ & $\mu / \mathrm{eV}$ & $\omega / \mathrm{eV}$ \\
\hline Isoproturon & -3.44 & -3.25 & 0.19 & 3.35 & 29.62 \\
Chlorotoluron & -7.10 & -0.58 & 6.52 & 3.84 & 1.13 \\
Diuron & -7.39 & -0.79 & 6.60 & 4.09 & 1.27 \\
Linuron & -7.47 & -0.84 & 6.63 & 4.16 & 1.30 \\
\hline
\end{tabular}

parameters derived from the Density Functional Theory. Global reactivity parameters indicate that isoproturon is the most reactive while linuron is the most stable. The Fukui function values suggest that electrophilic attacks on chlorotoluron, linuron, and diuron herbicides would cause the elimination of the urea moiety while electrophilic, nucleophilic, or free radical attacks on isoproturon would eliminate the isopropyl moiety in aqueous conditions.

\section{Conflict of Interests}

The author declares that there is no conflict of interests regarding the publication of this paper.

\section{Acknowledgments}

Luis Humberto Mendoza-Huizar gratefully acknowledges financial support from CONACYT (Project INFR-2014227999) and the Universidad Autónoma del Estado de Hidalgo through Projects PIFI 2008-13M8U0017T-04-01 y PIFI-2009-13MSU0017T-04-01. Luis Humberto MendozaHuizar wishes to thank National Laboratory for the Characterization of Physicochemical Properties and Molecular Structure (LACAPFEM) for providing supercomputing time.

\section{References}

[1] S. Giacomazzi and N. Cochet, "Environmental impact of diuron transformation: a review," Chemosphere, vol. 56, no. 11, pp. 10211032, 2004.

[2] S. R. Sørensen, C. N. Albers, and J. Aamand, "Rapid mineralization of the phenylurea herbicide diuron by Variovorax sp. strain SRS16 in pure culture and within a two-member consortium," Applied and Environmental Microbiology, vol. 74, no. 8, pp. 2332-2340, 2008.

[3] L. Vrielynck, C. Lapouge, S. Marquis, J. Kister, and N. Dupuy, "Theoretical and experimental vibrational study of phenylurea: structure, solvent effect and inclusion process with the $\beta$ cyclodextrin in the solid state," Spectrochimica Acta Part A, vol. 60, no. 11, pp. 2553-2559, 2004.

[4] F. Javier Benitez, C. Garcia, J. L. Acero, and F. J. Real, "Removal of phenylurea herbicides from waters by using chemical oxidation treatments," World Academy of Science, Engineering and Technology, vol. 3, pp. 10-22, 2009.

[5] M. Kaur, A. K. Malik, and B. Singh, "Determination of phenylurea herbicides in tap water and soft drink samples by HPLCUV and solid-phase extraction," LCGC North America, vol. 25, no. 3, pp. 120-129, 2012. 
[6] J. M. Sanchis-Mallols, S. Sagrado, M. J. Medina-Hernández, R. M. Villanueva Camañas, and E. Bonet-Domingo, "Determination of phenylurea herbicides in drinking waters by HPLC and solid phase extraction," Journal of Liquid Chromatography and Related Technologies, vol. 21, no. 6, pp. 869-881, 1998.

[7] D. Mackay, W. Y. Shiu, and K. C. Ma, Illustrated Handbook of Physical-Chemical Properties and Environmental Fate for Organic Chemicals, Volume 5: Pesticide Chemicals, Lewis, New York, NY, USA, 1997.

[8] Water Information System for Europe, Priority Substances and Certain Other Pollutants according to Annex II of Directive 2008/105/EC, Water Information system for Europe, 2015, http://ec.europa.eu/environment/water/water-framework/priority_substances.htm.

[9] World Health Organization, Guidelines for Drinking-Water Quality, Vol.2. Health Criteria and Other Supporting Information, World Health Organization, Geneva, Switzerland, 2nd edition, 1996.

[10] N. Badawi, S. Rønhede, S. Olsson et al., "Metabolites of the phenylurea herbicides chlorotoluron, diuron, isoproturon and linuron produced by the soil fungus Mortierella sp," Environmental Pollution, vol. 157, no. 10, pp. 2806-2812, 2009.

[11] M. Carrier, M. Besson, C. Guillard, and E. Gonze, "Removal of herbicide diuron and thermal degradation products under Catalytic Wet Air Oxidation conditions," Applied Catalysis B: Environmental, vol. 91, no. 1-2, pp. 275-283, 2009.

[12] J. Liu, "Phenylurea herbicides," in Handbook of Pesticide Toxicology: Volume 2: Principles, R. Krieger, Ed., Academic Press, San Diego, Calif, USA, 2001.

[13] U.S. Department of Health and Human Sevices. Public Health Service. Centers for Disease Control and Prevention National Institute for Occupational Safety and Health Education and Information Division, "Occupational safety and health guideline for Diuron,” February 2015, http://www.cdc.gov/niosh/ docs/81-123/pdfs/0247.pdf.

[14] S. Malato, J. Cáceres, A. R. Fernández-Alba et al., "Photocatalytic treatment of diuron by solar photocatalysis: evaluation of main intermediates and toxicity," Environmental Science and Technology, vol. 37, no. 11, pp. 2516-2524, 2003.

[15] M. EL Madani, C. Guillard, N. Pérol et al., "Photocatalytic degradation of diuron in aqueous solution in presence of two industrial titania catalysts, either as suspended powders or deposited on flexible industrial photoresistant papers," Applied Catalysis B: Environmental, vol. 65, no. 1-2, pp. 70-76, 2006.

[16] M. Carrier, C. Guillard, M. Besson, C. Hordes, and H. Chermette, "Photocatalytic degradation of diuron: experimental analyses and simulation of $\mathrm{HO}^{\circ}$ radical attacks by density functional theory calculations," Journal of Physical Chemistry A, vol. 113, no. 22, pp. 6365-6374, 2009.

[17] P. A. K. Reddy, P. V. L. Reddy, V. M. Sharma, B. Srinivas, V. D. Kumari, and M. Subrahmanyam, "Photocatalytic degradation of isoproturon pesticide on $\mathrm{C}, \mathrm{N}$ and $\mathrm{S}$ doped $\mathrm{TiO}_{2}$," Journal of Water Resource and Protection, vol. 2, pp. 235-244, 2010.

[18] F. Ruggieri, A. A. D’Archivio, M. Fanelli, and S. Santucci, "Photocatalytic degradation of linuron in aqueous suspensions of $\mathrm{TiO}_{2}$," RSC Advances, vol. 1, no. 4, pp. 611-618, 2011.

[19] H. Katsumata, M. Sada, Y. Nakaoka, S. Kaneco, T. Suzuki, and K. Ohta, "Photocatalytic degradation of diuron in aqueous solution by platinized $\mathrm{TiO}_{2}$," Journal of Hazardous Materials, vol. 171, no. 1-3, pp. 1081-1087, 2009.
[20] A. Amorisco, I. Losito, T. Carbonara, F. Palmisano, and P. G. Zambonin, "Photocatalytic degradation of phenyl-urea herbicides chlortoluron and chloroxuron: characterization of the by-products by liquid chromatography coupled to electrospray ionization tandem mass spectrometry," Rapid Communications in Mass Spectrometry, vol. 20, no. 10, pp. 1569-1576, 2006.

[21] S. Aquino and A. Rodrigues, "Electrochemical oxidation of herbicides," in Herbicides, Theory and Applications, M. Larramendy, Ed., InTech, Rijeka, Croatia, 2011.

[22] S. Nélieu, F. Perreau, F. Bonnemoy et al., "Sunlight nitrateinduced photodegradation of chlorotoluron: evidence of the process in aquatic mesocosms," Environmental Science and Technology, vol. 43, no. 9, pp. 3148-3154, 2009.

[23] Y. C. Lu, S. Zhang, S. S. Miao et al., "Enhanced degradation of herbicide isoproturon in wheat rhizosphere by salicylic acid," Journal of Agricultural and Food Chemistry, vol. 63, no. 1, pp. 92-103, 2015.

[24] P. Miriti, G. Magoma, H. I. Boga, and A. Nyende, "Isolation and characterization of linuron degrading bacteria from soils under horticultural production in Kenya," International Journal of Environmental Bioremediation \& Biodegradation, vol. 2, no. 5, pp. 220-227, 2014.

[25] J. Safi, Y. Awad, and Y. El-Nahhal, "Bioremediation of diuron in soil environment: influence of cyanobacterial mat," The American Journal of Plant Sciences, vol. 05, no. 08, pp. 1081-1089, 2014.

[26] G. A. Turnbull, M. Ousley, A. Walker, E. Shaw, and J. A. W. Morgan, "Degradation of substituted phenylurea herbicides by arthrobacter globiformis strain D47 and characterization of a plasmid-associated hydrolase gene, puhA," Applied and Environmental Microbiology, vol. 67, no. 5, pp. 2270-2275, 2001.

[27] L. Ellegaard-Jensen, B. E. Knudsen, A. Johansen, C. N. Albers, J. Aamand, and S. Rosendahl, "Fungal-bacterial consortia increase diuron degradation in water-unsaturated systems," Science of the Total Environment, vol. 466-467, pp. 699-705, 2014.

[28] R. L. Arakaki, D. A. Monteiro, M. Boscolo, R. Dasilva, and E. Gomes, "Halotolerance, ligninase production and herbicide degradation ability of basidiomycetes strains," Brazilian Journal of Microbiology, vol. 44, no. 4, pp. 1207-1214, 2013.

[29] C. Tixier, P. Bogaerts, M. Sancelme et al., "Fungal biodegradation of a phenylurea herbicide, diuron: structure and toxicity of metabolites," Pest Management Science, vol. 56, no. 5, pp. 455$462,2000$.

[30] F. Galichet, G. Mailhot, F. Bonnemoy, J. Bohatier, and M. Bolte, "Iron(III) photo-induced degradation of isoproturon: correlation between degradation and toxicity," Pest Management Science, vol. 58, no. 7, pp. 707-712, 2002.

[31] F. Bonnemoy, B. Lavédrine, and A. Boulkamh, "Influence of UV irradiation on the toxicity of phenylurea herbicides using Microtox test," Chemosphere, vol. 54, no. 8, pp. 1183-1187, 2004.

[32] A. Amine-Khodja, A. Boulkamh, and P. Boule, "Photochemical behaviour of phenylurea herbicides," Photochemical \& Photobiological Sciences, vol. 3, no. 2, pp. 145-156, 2004.

[33] H. Singh, Mycoremediation: Fungal Bioremediation, John Wiley \& Sons, New York, NY, USA, 2006.

[34] P. Quevauviller, A. Fouillac, J. Grath, and R. Ward, Groundwater Monitoring, John Wiley \& Sons, Chichester, UK, 2009.

[35] T. Gu, C. Zhou, S. R. Sørensen et al., "The novel bacterial $\mathrm{N}$-demethylase $\mathrm{PdmAB}$ is responsible for the initial step of 
N, N-dimethyl-substituted phenylurea herbicide degradation," Applied and Environmental Microbiology, vol. 79, no. 24, pp. 7846-7856, 2013.

[36] D. Fabbri, M. Minella, V. Maurino, C. Minero, and D. Vione, "Photochemical transformation of phenylurea herbicides in surface waters: a model assessment of persistence, and implications for the possible generation of hazardous intermediates," Chemosphere, vol. 119, pp. 601-607, 2015.

[37] F. Worrall and M. Thomsen, "Quantum vs. topological descriptors in the development of molecular models of groundwater pollution by pesticides," Chemosphere, vol. 54, no. 4, pp. 585596, 2004.

[38] B. Kanawati, M. Harir, and P. Schmitt-Kopplin, "Exploring Rearrangements along the Fragmentation Pathways of Diuron Anion: a combined experimental and computational investigation," International Journal of Mass Spectrometry, vol. 288, no. 1-3, pp. 6-15, 2009.

[39] Q. Wang and H. L. Wang, "THz spectroscopic investigation of chlorotoluron by solid-state density functional theory," Chemical Physics Letters, vol. 534, pp. 72-76, 2012.

[40] L. Vrielynck, N. Dupuy, J. Kister, and G. Nowogrocki, "Molecular structure and vibrational spectroscopy of isoproturon," Journal of Molecular Structure, vol. 788, no. 1-3, pp. 232-237, 2006.

[41] J. L. Gázquez, "Perspectives on the density functional theory of chemical reactivity," Journal of the Mexican Chemical Society, vol. 52, no. 1, pp. 3-10, 2008.

[42] P. Geerlings, F. de Proft, and W. Langenaeker, "Conceptual density functional theory," Chemical Reviews, vol. 103, no. 5, pp. 1793-1874, 2003.

[43] H. Chermette, "Chemical reactivity indexes in density functional theory," Journal of Computational Chemistry, vol. 20, no. 1, pp. 129-154, 1999.

[44] P. W. Ayers, J. S. M. Anderson, and L. J. Bartolotti, "Perturbative perspectives on the chemical reaction prediction problem," International Journal of Quantum Chemistry, vol. 101, no. 5, pp. 520-534, 2005.

[45] P. K. Chattaraj, U. Sarkar, and D. R. Roy, "Electrophilicity index," Chemical Reviews, vol. 106, no. 6, pp. 2065-2091, 2006.

[46] P. A. Johnson, L. J. P. Bartolotti, W. Ayers, T. Fievez, and P. Geerlings, Modern Charge Density Analysis, edited by: C. Gatti, P. Macchi, Springer, New York, NY, USA, 2012.

[47] S.-B. Liu, "Conceptual density functional theory and some recent developments," Acta Physico-Chimica Sinica, vol. 25, no. 3, pp. 590-600, 2009.

[48] R. G. Parr, R. A. Donnelly, M. Levy, and W. E. Palke, "Electronegativity: the density functional viewpoint," The Journal of Chemical Physics, vol. 68, no. 8, pp. 3801-3807, 1977.

[49] R. G. Parr and R. G. Pearson, "Absolute hardness: companion parameter to absolute electronegativity," Journal of the American Chemical Society, vol. 105, no. 26, pp. 7512-7516, 1983.

[50] R. G. Pearson, "Recent advances in the concept of hard and soft acids and bases," Journal of Chemical Education, vol. 64, no. 7, pp. 561-567, 1987.

[51] R. G. Parr, L. V. Szentpály, and S. Liu, "Electrophilicity index," Journal of the American Chemical Society, vol. 121, no. 9, pp. 1922-1924, 1999.

[52] R. G. Parr and W. Yang, Density Functional Theory of Atoms and Molecules, Oxford University Press, New York, NY, USA, 1989.
[53] S. B. Liu, "Electrophilicity", in Chemical Reactivity Theory: A Density Functional View, P. K. Chattaraj, Ed., chapter 13, p. 179, Taylor \& Francis, Boca Raton, Fla, USA, 2009.

[54] J. L. Gâzquez and F. Méndez, "The hard and soft acids and bases principle: an atoms in molecules viewpoint," Journal of Physical Chemistry, vol. 98, no. 17, pp. 4591-4593, 1994.

[55] F. Méndez and J. L. Gázquez, "Chemical reactivity of enolate ions: the local hard and soft acids and bases principle viewpoint," Journal of the American Chemical Society, vol. 116, no. 20, pp. 9298-9301, 1994.

[56] R. G. Parr and W. Yang, "Density functional approach to the frontier-electron theory of chemical reactivity," Journal of the American Chemical Society, vol. 106, no. 14, pp. 4049-4050, 1984.

[57] A. D. Becke, "Density-functional thermochemistry. III. The role of exact exchange," The Journal of Chemical Physics, vol. 98, no. 7, pp. 5648-5652, 1993.

[58] A. D. Becke, "Density-functional exchange-energy approximation with correct asymptotic behavior," Physical Review A, vol. 38, no. 6, pp. 3098-3100, 1988.

[59] C. Lee, W. Yang, and R. G. Parr, "Development of the ColleSalvetti correlation-energy formula into a functional of the electron density," Physical Review B, vol. 37, no. 2, pp. 785-789, 1988.

[60] R. Krishnan, J. S. Binkley, R. Seeger, and J. A. Pople, "Selfconsistent molecular orbital methods. XX. A basis set for correlated wave functions," The Journal of Chemical Physics, vol. 72, no. 1, pp. 650-654, 1980.

[61] A. D. McLean and G. S. Chandler, "Contracted Gaussian basis sets for molecular calculations. I. Second row atoms, $\mathrm{Z}=11-18$," The Journal of Chemical Physics, vol. 72, no. 10, pp. 5639-5648, 1980.

[62] S. Miertus and J. Tomasi, "Approximate evaluations of the electrostatic free energy and internal energy changes in solution processes," Chemical Physics, vol. 65, no. 2, pp. 239-245, 1982.

[63] S. Miertš, E. Scrocco, and J. Tomasi, "Electrostatic interaction of a solute with a continuum. A direct utilizaion of $A B$ initio molecular potentials for the prevision of solvent effects," Chemical Physics, vol. 55, no. 1, pp. 117-129, 1981.

[64] M. Head-Gordon, J. A. Pople, and M. J. Frisch, "MP2 energy evaluation by direct methods," Chemical Physics Letters, vol. 153, no. 6 , pp. 503-506, 1988.

[65] M. J. Frisch, G. W. Trucks, H. B. Schlegel et al., Gaussian 09, Revision A.01, Gaussian, Wallingford, Conn, USA, 2009.

[66] GaussView Version: 3.09, Windows Version, Gaussian, Pittsburgh, Pa, USA, 2003.

[67] S. Gunasekaran, R. K. Natarajan, D. Syamala, and R. Rathikha, "Normal Coordinate ananlysis of urea meta nitro benzoic acid crystal," Indian Journal of Pure \& Applied Physics, vol. 44, no. 4, pp. 315-319, 2006.

[68] L. Vrielynck, C. Lapouge, S. Marquis, J. Kister, and N. Dupuy, "Theoretical and experimental vibrational study of phenylurea: structure, solvent effect and inclusion process with the $\beta$ cyclodextrin in the solid state," Spectrochimica Acta A, vol. 60, no. 11, pp. 2553-2559, 2004.

[69] T. Vroumsia, R. Steiman, F. Seigle-Murandi, J.-L. Benoit-Guyod, and A. Khadrani, "Biodegradation of three substituted phenylurea herbicides (chlortoluron, diuron, and isoproturon) by soil fungi. A comparative study," Chemosphere, vol. 33, no. 10, pp. 2045-2056, 1996. 
[70] F. L. Hirshfeld, "Bonded-atom fragments for describing molecular charge densities," Theoretica Chimica Acta, vol. 44, no. 2, pp. 129-138, 1977.

[71] J. Padmanabhan, R. Parthasarathi, U. Sarkar, V. Subramanian, and P. K. Chattaraj, "Effect of solvation on the condensed Fukui function and the generalized philicity index," Chemical Physics Letters, vol. 383, no. 1-2, pp. 122-128, 2004. 

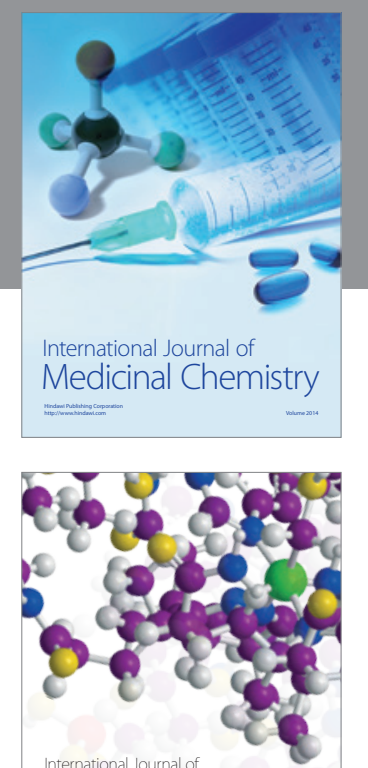

\section{Carbohydrate} Chemistry

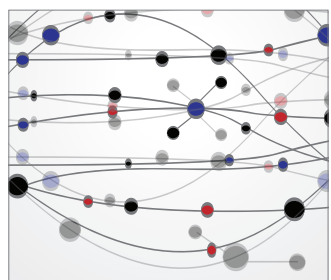

The Scientific World Journal
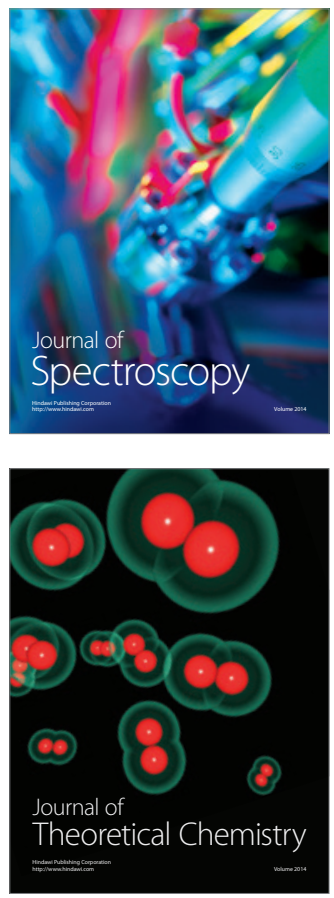
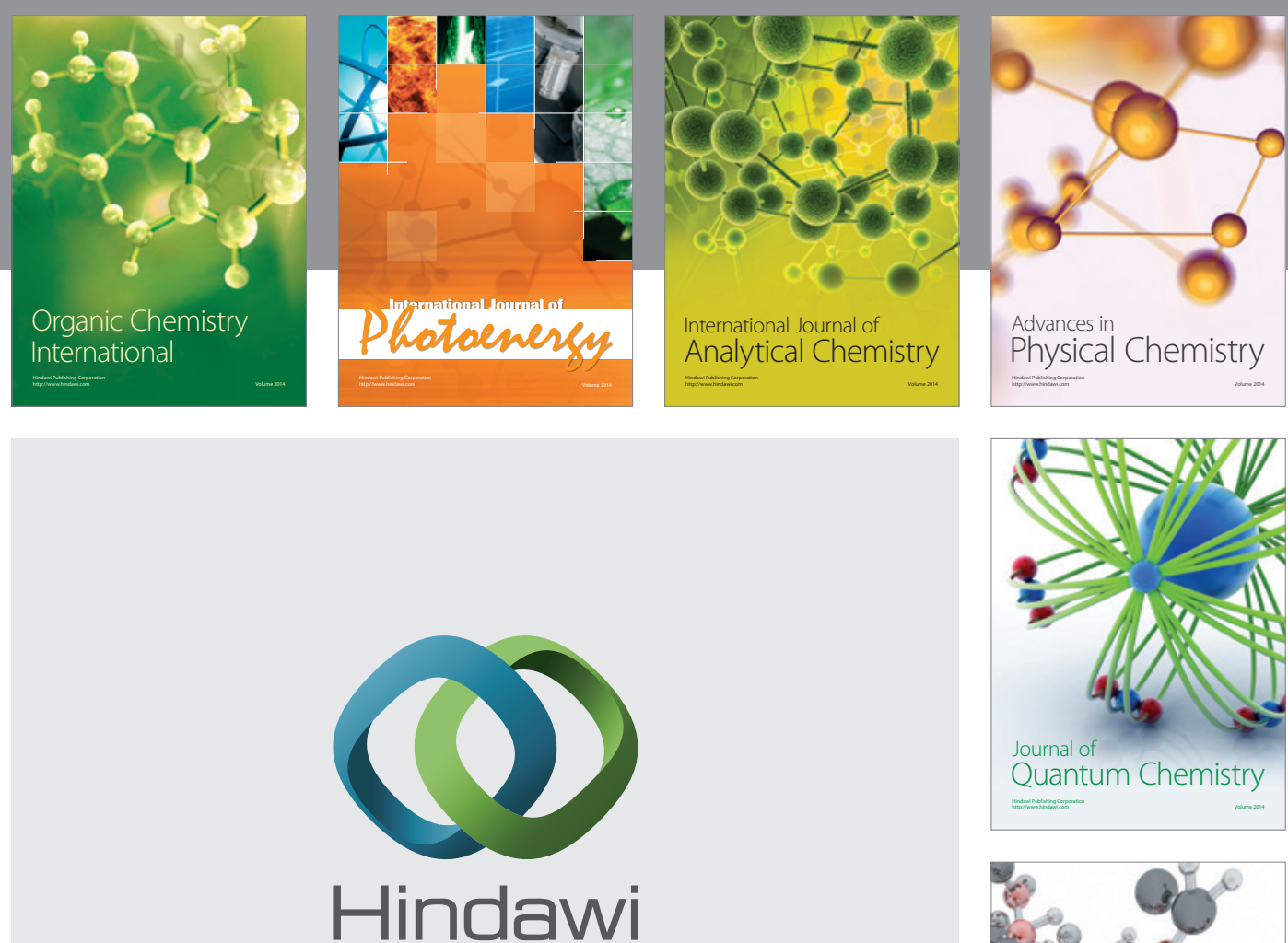

Submit your manuscripts at

http://www.hindawi.com

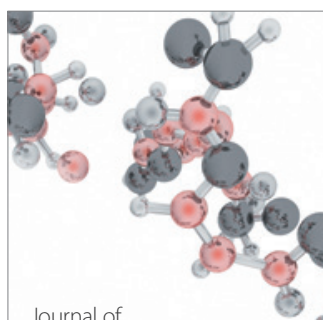

Analytical Methods

in Chemistry

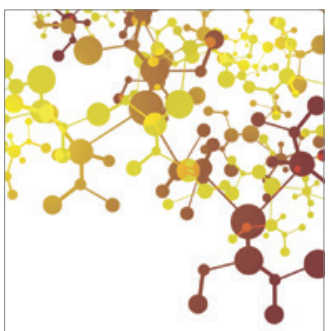

Journal of

Applied Chemistry

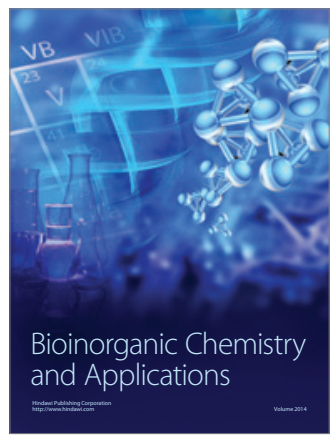

Inorganic Chemistry
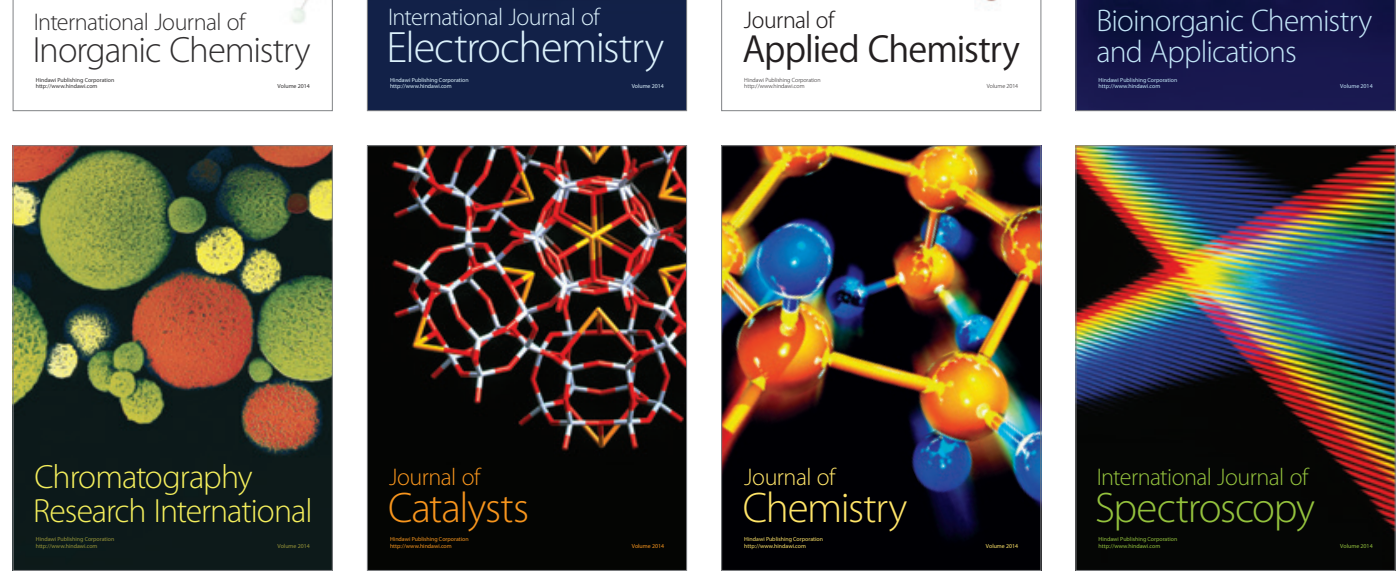